\title{
Karakteristik Mikrosatelit Gen BoLA dengan Penanda Primer RM 185 pada Sapi Bali (Bos indicus) di Nusa Penida
}

\section{Characteristics of Gene BoLA Microsatellite with Primer RM 185 in Bali Cattle (Bos} indicus) from Nusa Penida

\author{
Putu Suastika", I Ketut Puja, I Nengah Wandia, dan I Nyoman Sulabda
}

Fakultas Kedokteran Hewan, Universitas Udayana,

Jln. PB. Sudirman Denpasar Bali

E-mail: suastikafkh@yahoo.com ${ }^{*}$ Penulis untuk korespondensi

\begin{abstract}
This study aim to describe the gene frequency distribution of the bovine lymphocyte antigen (BoLA) locus using primer RM 185 in Bali catlle from Nusa Penida. Twenty one bali cattle from Nusa Penida were studied randomly for polymorphism in BoLA gene. The numbers of alleles locus RM 185 gene were 7 allel each 76 pb, 84 pb, 86 pb, 90 pb, 98 pb, 100 pb, and 104 pb. The frequency allel was observed were each $0.02 \%, 0.09 \%, 0.31 \%, 0.07 \%, 0.12 \%, 0.28 \%$, and $0.09 \%$. The average heterozygosity observed were 0.804 . Conclusion of this study demonstrated that BoLA gene in locus RM 185 is a highly polymorphic locus in Bali cattle, with significant variation in ellele frequency among cattle breeds.
\end{abstract}

Keywords: Bali cattle, primer RM 185, BoLA gene, heterozygosity

Abstrak

Penelitian ini bertujuan menjelaskan distribusi frekuensi lokus gen bovine lymphocyte antigen (BoLA) memakai primer RM 185 pada sapi bali dari Nusa Penida. Sebanyak 21 ekor sapi bali yang berasal dari Nusa Penida diambil secara acak. Jumlah alel gen BoLA pada lokus RM 185 ada 7 macam alel yaitu 76 pb, 84 pb, 86 pb, 90 pb, 98 pb, 100 pb, dan 104 pb. Frekuensi tiaptiap alel yang teramati adalah $0,02 \% ; 0,09 \% ; 0,31 \% ; 0,07 \% ; 0,12 \% ; 0,28 \%$; dan $0,09 \%$. Ratarata heterozigositas yang didapat adalah 0,804. Dapat disimpulkan, bahwa lokus RM 185 pada gen BoLA sapi bali di Nusa Penida adalah sangat polimorfik di antara populasi.

Kata kunci: Sapi bali, penanda RM 185, gen BoLA-DRB, heterozigositas 